\title{
Hubungan SPL dan Salinitas Terhadap Hasil Tangkapan Cakalang pada KM. Samudra Jaya di Laut Maluku
}

\author{
[Relationship of SPT and Salinity to Catch of Skipjack \\ on FV. Samudera Jaya in Moluccas Sea]
}

\section{Priyo Adi Pamungkas, Afriana Kusdinar, Sugianto Halim}

Jurusan Teknologi Penangkapan Ikan, Sekolah Tinggi Perikanan

JI. AUP Pasar Minggu Jakarta Selatan 12520 Indonesia

\begin{abstract}
Abstrak
Upaya memprediksi daerah penangkapan ikan cakalang dilakukan melalui pendekatan fisik parameter oseanografi. Penelitian bertujuan menentukan hubungan suhu permukaan laut (SPL) dan salinitas terhadap jumlah dan ukuran panjang, menganalisa komposisi jumlah dan ukuran layak tangkap dan tidak layak tangkap ikan cakalang, mengetahui sebaran suhu permukaan laut dan salinitas di Laut Maluku. Penelitian ini dilakukan dengan metode experimental fishing melalui pengambilan data secara in-situ, dan analisa data citra satelit Suhu Permukaan Laut (SPL) dan Salinitas yang diperoleh dengan mendownload dari laman http://oceancolor.gsfc.nasa.gov dan http://peta.maritim.BMKG.id/statistic. SPL di Laut Maluku pada bulan Desember 2018 berkisar $29-30^{\circ} \mathrm{C}$ dengan suhu dominan $30^{\circ} \mathrm{C}$, kisaran SPL Januari $201928-30^{\circ} \mathrm{C}$ dengan suhu dominan $29^{\circ} \mathrm{C}$, bulan Februari 2019 berkisar $29-30^{\circ} \mathrm{C}$ dengan suhu dominan $29^{\circ} \mathrm{C}$ dan untuk bulan Maret berkisar $28-31^{\circ} \mathrm{C}$ dengan suhu dominan $28^{\circ} \mathrm{C}$. Kemudian, salinitas bulan Desember 2018-Januari 2019 berkisar 33,5-34\%, bulan Februari-Maret berkisar 33,5-35\%.lkan cakalang sering tertangkap pada kisaran suhu $28-30^{\circ} \mathrm{C}$ dan salinitas $30-33 \%$. Ikan cakalang berukuran besar lebih lebih dominan tertangkap pada suhu $28-28,9^{\circ} \mathrm{C}$ memiliki ukuran $36,4 \mathrm{~cm}$ dan salinitas 32 dengan ukuran $37,6 \mathrm{~cm}$. Suhu dan salinitas tidak berpengaruh terhadap jumlah dan ukuran panjang ikan cakalang dari hasil tangkapan di Laut Maluku. Dengan masing-masing memiliki nilai $r=0,024, r=0,030$ untuk suhu terhadap jumlah dan ukuran panjang ikan dan untuk nilai $r=0,030$, $r=0,028$ untuk salinitas terhadap jumlah dan ukuran panjang ikan.
\end{abstract}

Kata kunci: cakalang; Laut Maluku; salinitas; suhu permukaan laut

\section{Abstract}

The efforts to predict skipjack fishing areas through a physical approach to oceanographic parameters. This study aims to determine the relationship between sea surface temperature (SPL) and salinity on the number and length, to analyze the composition of the number and size of catch and unfit to catch skipjack tuna, knowing the distribution of sea surface temperature and salinity in the Maluku Sea. This research was conducted using experimental fishing methods through in-situ data collection, and analysis of sea surface temperature (SPL) and salinity satellite imagery data obtained by downloading from the http://oceancolor.gsfc.nasa.gov and http: // pages. peta.maritim.BMKG.id/statistic. SST in the Maluku Sea in December 2018 ranges from $29-30^{\circ} \mathrm{C}$ with a dominant temperature of $30^{\circ} \mathrm{C}$, the range of SST in January 2019 is $28-30^{\circ} \mathrm{C}$ with a dominant temperature of $29^{\circ} \mathrm{C}$, in February 2019 it ranges from $29-30^{\circ} \mathrm{C}$ with a dominant temperature of $29^{\circ} \mathrm{C}$ and for March the range is $28-31^{\circ} \mathrm{C}$ with a dominant temperature of $28^{\circ}$ C. Then, the salinity of December 2018-January 2019 ranges from $33.5-34 \% /$, February-March ranges from $33.5-35^{\circ} / \infty$. Skipjack tuna is often caught in the temperature range $28-30^{\circ} \mathrm{C}$ and salinity $30-33^{\circ} / \infty$. Large skipjack tuna are more dominant when caught at $28-28.9^{\circ} \mathrm{C}$ with a size of $36.4 \mathrm{~cm}$ and a salinity of 32 with a size of $37.6 \mathrm{~cm}$. Temperature and salinity do not affect the number and length of skipjack tuna from the catch in the Maluku Sea. With each having a value of $r=0.024, r=0.030$ for the temperature for the number and length of fish and for the value of $r=0.030, r=0.028$ for the salinity for the number and length of fish.

Keywords: Moluccas Sea; salinity; sea surface temperature; skipjack tuna 


\section{Penulis Korespondensi}

Priyo Adi Pamungkas | rioapamungkas96@gmail.com

\section{PENDAHULUAN}

Ikan cakalang (Katsuwonus pelamis) tergolong sumberdaya perikanan pelagis penting di Kota Bitung dengan daerah penangkapan hampir diseluruh Laut Sulawesi sampai ke Laut Maluku. Ikan cakalang hidup bergerombol dalam jumlah yang sangat besar, sehingga ikan ini paling sering tertangkap oleh nelayan dengan menggunakan purse seine (pukat cincin), pole and line (huhate), pancing ulur (hand line), pancing tonda (trolling line) dan jaring insang (drift surface gillnet).

Bitung merupakan kota di Sulawesi Utara yang menjadi pusat industri perikanan cakalang terbesar di Kawasan Indonesia Timur. Kota Bitung sangat strategis terletak di antara dua wilayah pengelolaan perikanan meliputi Laut Maluku (WPP-715) dan Laut Sulawesi (WPP-716). Nilai potensi tuna yang bisa dimanfaatkan atau ditangkap di perairan Sulawesi Utara sebesar 14,173.51 ton/tahun atau $80 \%$ dari nilai pemanfaatan sumber daya perikanan tangkap tuna (Simanjuntak, Lumingas, dan Sangari 2019).

Ikan cakalang merupakan ikan pelagis besar yang memiliki karakteristik oseanik atau memiliki sifat selalu beruaya dari suatu perairan keperairan lain yang mempunyai kondisi oseanografi, biologis dan meteorologis yang sesuai dengan habitatnya. (Sibagariang, Fauziyah, dan Agustriani 2011). Penyebaran ikan cakalang di Indonesia meliputi, Pantai barat Sumatera, Selatan Jawa, Bali Nusa Tenggara, perairan Indonesia Timur meliputi Laut Banda, Laut Flores, Laut Maluku dan Laut Makasar (Firdaus 2018).

Salah satu parameter oseanografi yang memiliki pengaruh terhadap kehidupan ikan dan sumber daya hayati laut lainnya adalah suhu, sedangkan salinitas berkaitan erat dengan penyesuian tekanan osmotik yang memiliki ikatan erat dengan kehidupan organisme perairan termasuk ikan (Tangke et al. 2016). Parameter tersebut dapat digunakan untuk memprediksi keberadaan kelompok ikan khususnya cakalang, sehingga informasi tersebut dapat digunakan sebagai indikator daerah penangkapan ikan yang potensial.

Data yang dihasilkan dari parameter tersebut, selanjutnya dianalisa sehingga menghasilkan interaksi distribusi daerah penangkapan ikan cakalang yang potensial di Laut Maluku. Dalam rangka mengetahui interaksi parameter suhu permukaan laut (SPL) dan salinitas terhadap hasil 


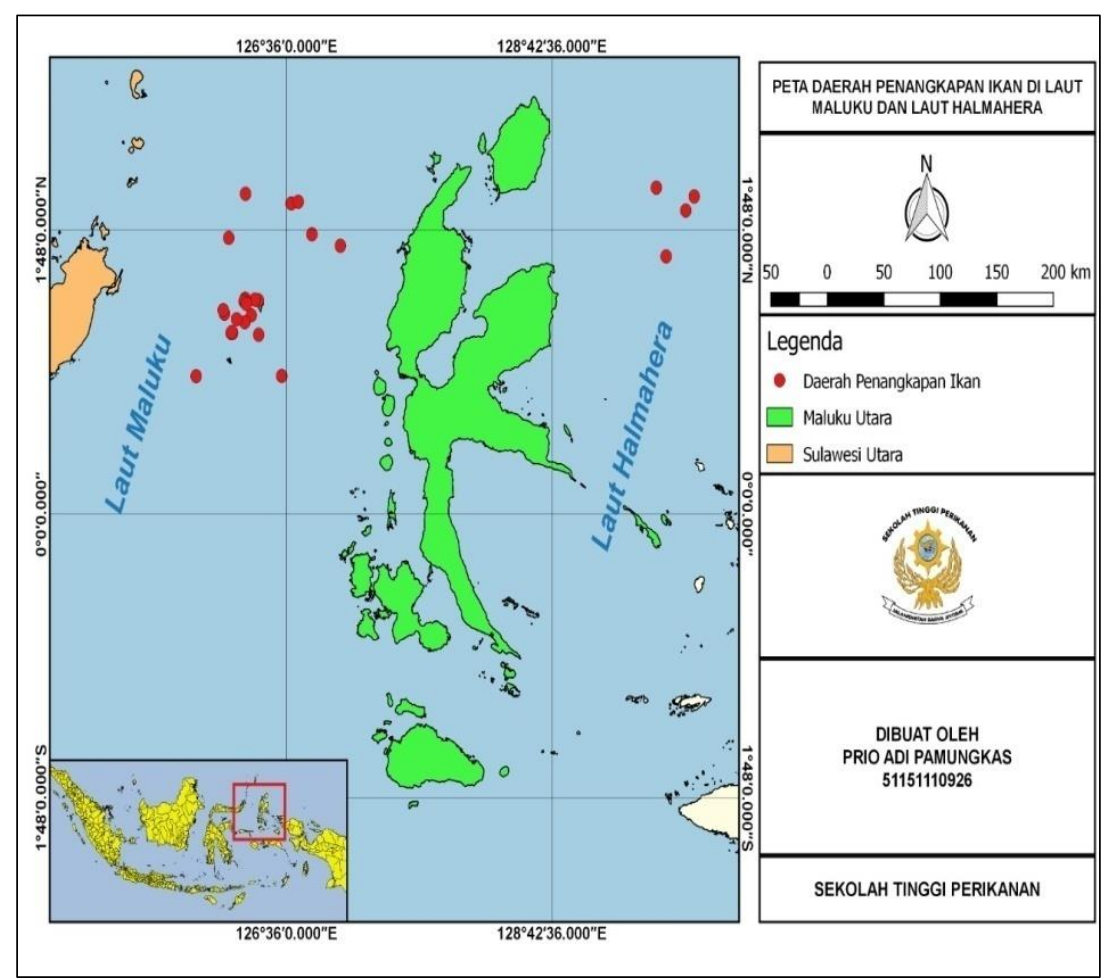

Gambar 1. Peta lokasi penelitian

tangkapan dan ukuran panjang ikan kita dapat melihat sebagian sifat-sifat ikan cakalang dalam mengatasi perubahan lingkungan. Penelitian ini bertujuan untuk mengetahui hubungan suhu permukaan laut (SPL) dan salinitas terhadap jumlah dan ukuran panjang ikan cakalang, menganalisa komposisi jumlah dan ukuran layak tangkap dan tidak layak tangkap ikan cakalang. Serta mengetahui sebaran suhu permukaan laut dan salinitas di Laut Maluku.

\section{BAHAN DAN METODE}

Metode yang digunakan dalam penelitian ini adalah metode experimental fishing yaitu melalui pengamatan langsung terhadap kegiatan penangkapan ikan cakalang dengan menggunakan unit penangkapan pukat cincin. Sampel pukat cincin ditentukan sebanyak 2 unit secara sengaja (purposive sampling) dengan daerah penangkapan yang berbeda yaitu WPP 715 dan WPP 717

Data yang dikumpulkan pada setiap sampel pukat cincin adaalah posisi lintang dan bujur, waktu operasi penangkapan, jumlah dan ukuran panjang (size) ikan cakalang yang tertangkap. Data tersebut dicatat kedalam jurnal harian penangkapan dalam bentuk logbook pada setiap kapal. Data kegiatan penangkapan juga diperoleh melalui wawancara terhadap responden dua puluh orang yang terdiri 
Tabel 1. Komposisi hasil tangkapan ikan cakalang bulan Desember 2018-Maret 2019

\begin{tabular}{lcccc}
\hline Bulan & Frekuensi & $\begin{array}{c}\text { Jumlah Hasil } \\
\text { Tangkapan Ikan } \\
(\mathbf{K g})\end{array}$ & $\begin{array}{c}\text { Rata-rata } \\
\mathbf{( k g )}\end{array}$ & $\begin{array}{c}\text { Presentase } \\
\mathbf{( \% )}\end{array}$ \\
\hline Desember & 5 & 10.200 & 2.040 & 17,9 \\
Januari & 7 & 28.970 & 4,138 & 50,6 \\
Februari & 9 & 15.700 & 1,744 & 27,4 \\
Maret & 4 & 2400 & 600 & 4,1 \\
\hline Total & 25 & 57.270 & & 100 \\
\hline
\end{tabular}

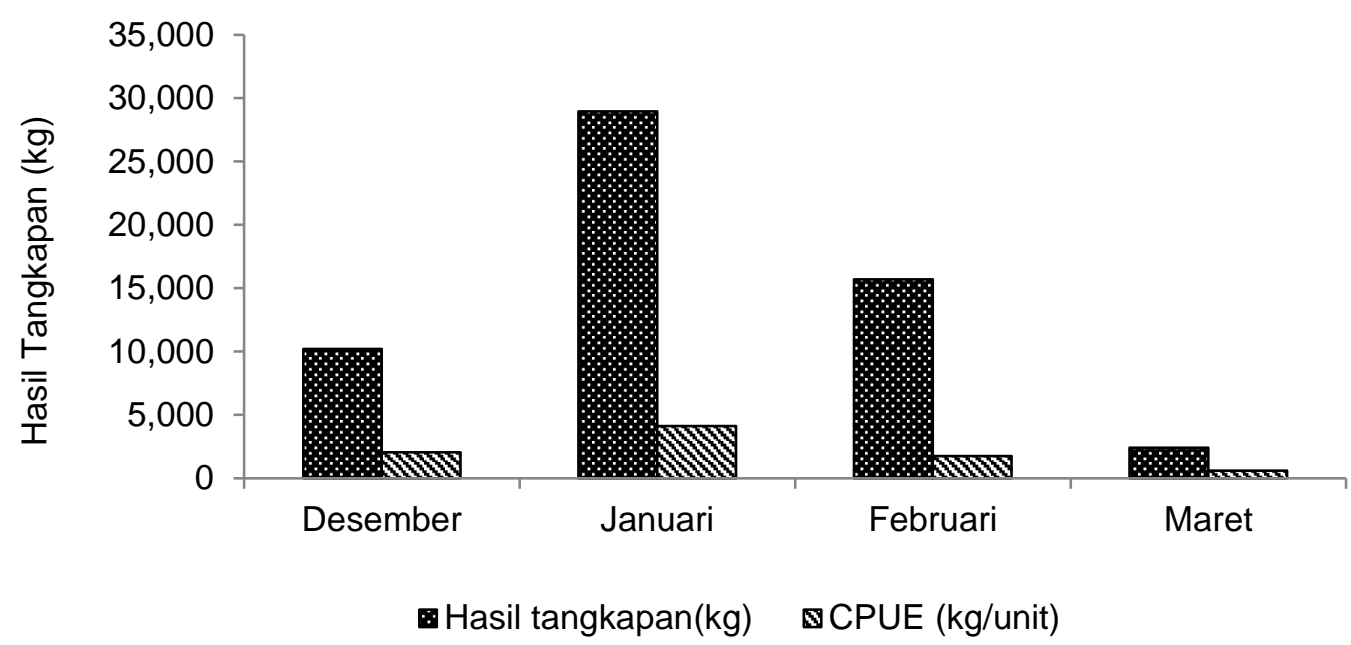

Gambar 2. Hasil tangkapan Cakalang dan CPUE bulan Desember 2018-Maret 2019

dari sepuluh orang anak buah kapal (ABK), dua orang nahkoda kapal yang berbeda dan delapan orang karyawan perusaahan. Data hasil tangkapan ikan cakalang pada bulan Desember 2018Maret 2019 disajikan pada Tabel 1 dan Gambar 2.

Data sebaran SPL dan Salinitas diambil secara in-situ dengan analisa data citra satelit SPL dan Salinitas yang diperoleh dengan mendownload dari laman http://oceancolor.gsfc.nasa.gov dan http://peta.maritim.BMKG.id/ statistic. Data SPL yang dipilih merupakan data bulanan sebaran SPL level 2 pada citra Aqua MODIS posisi geografis $\quad 00^{\circ} 52^{\prime \prime}, 24^{\prime} \mathrm{LS}-01^{\circ} 37,{ }^{\prime}, 53^{\prime} \mathrm{LU}$ dan $125^{\circ} 53^{\prime}, 22^{\prime \prime}$ BT $129^{\circ} 36^{\prime \prime}, 82^{\prime B T}$.

Frekuensi ukuran panjang cakalang yang tertangkap menurut periode waktu (bulanan dan harian) selama peneltian disajikan dalam bentuk diagram (Gambar 3 dan 4). Sebaran ukuran panjang ini digunakan untuk menentukan kategori ikan yang sudah layak tangkap dan belum layak tangkap 


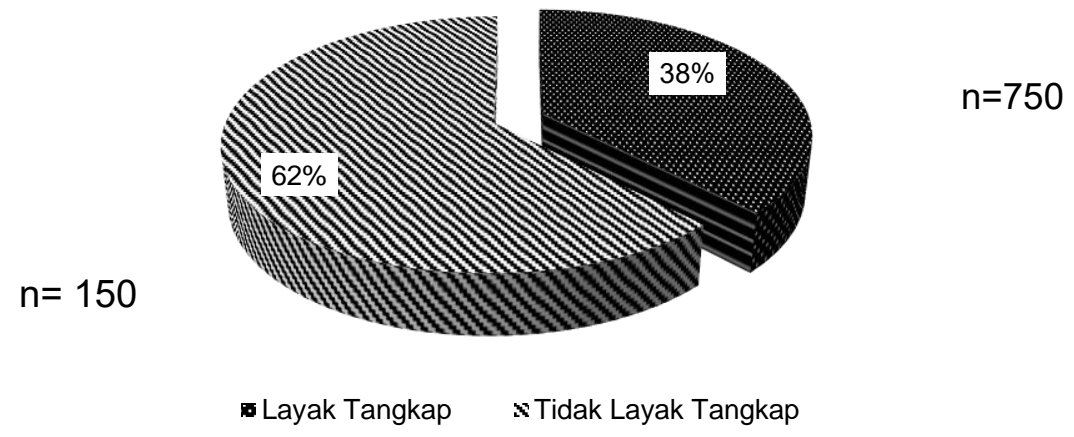

Gambar 3. Presentase total ikan layak tangkap dan tidak layak tangkap

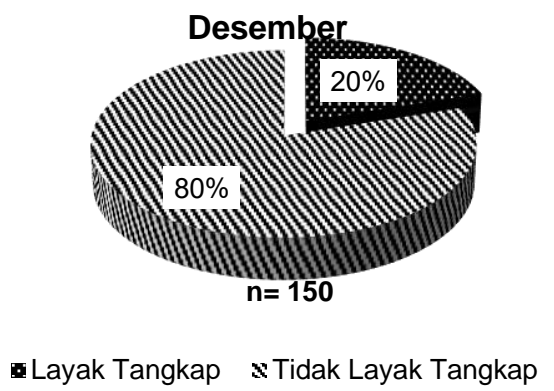

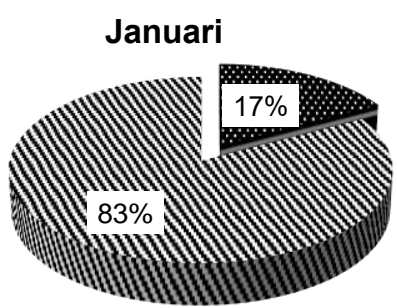

$\mathrm{n}=\mathbf{2 1 0}$

x Layak Tangkap s Tidak Layak Tangkap

Gambar 4. Presentase ukuran ikan layak tangkap dan tidak layak tangkap bulan Desember 2018 sampai Januari 2019

dalam mengevaluasi ukuran mata jaring yang digunakan. Pengelompokan ukuran panjang ikan ini didasarkan pada ukuran ikan cakalang yang sudah dewasa yaitu mulai ukuran $40 \mathrm{~cm}$ (Matsumoto, Skillman, dan Dizon 1984).

Pengaruh variabel SPL dan Salinitas terhadap jumlah dan ukuran panjang ikan cakalang dilakukan dengan analisis korelasi dengan menetukan hubungan antara variabel SPL dan Salinitas dengan Variabel jumlah dan ukuran panjang ikan cakalang. Semakin tinggi nilai korelasi maka hubungan akan semakin kuat dan erat. Hubungan dinyatakan dengan koefisien korelasi $(r)$ sebagai berikut (Walpole 1995):

$$
\begin{gathered}
a=\frac{\left(\sum Y\right)\left(\sum X^{2}\right)}{n\left(\sum X^{2}\right)\left(\sum X\right)^{2}} \\
b=\frac{\left(n \sum X Y\right)-\left(\sum X\right)\left(\sum Y\right)}{n \sum X^{2}-\left(\sum X\right)^{2}}
\end{gathered}
$$

Keterangan :

$\mathrm{N}=$ jumlah sampel

$\mathrm{a}=$ bilangan konstanta yang akan mempengaruhi arah regresi linear

$\mathrm{b}=$ slope

$\mathrm{y}=$ variabel tidak bebas (Ikan Hasil Tangkapan) $\mathrm{x} 1=$ variabel bebas (Suhu) 


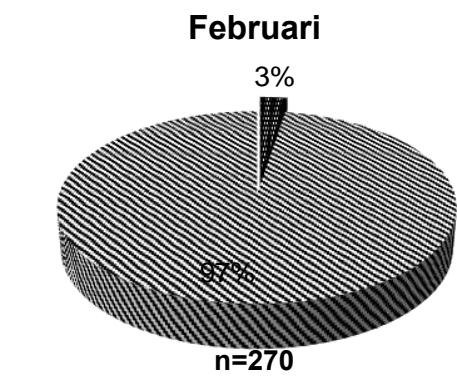

- Laya Tangkap sTidak Layak Tangkap
Maret

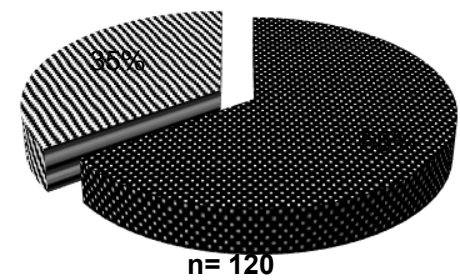

- Layak Tangkap $\quad$ s Tidak Layak Tangkap

Gambar 5. Presentase ukuran ikan layak tangkap dan tidak layak tangkap bulan Februari sampai Maret 2019

Tabel 2. Hasil tangkapan ikan Cakalang berdasarkan SPL

\begin{tabular}{rcccc}
\hline Suhu ${ }^{\circ} \mathrm{C}$ & $\mathbf{2 8 . 0 0 - 2 8 . 5 9}$ & $\mathbf{2 8 . 6} \mathbf{- 2 9 . . 9}$ & $\mathbf{2 9 . 2 - 2 9 . 7 9}$ & $\mathbf{2 9 . 8 - 3 0 . 3 9}$ \\
\hline Cakalang $(\mathrm{kg})$ & 2,913 & 1,550 & 2,600 & 1,225 \\
\hline
\end{tabular}

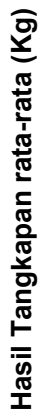
2913

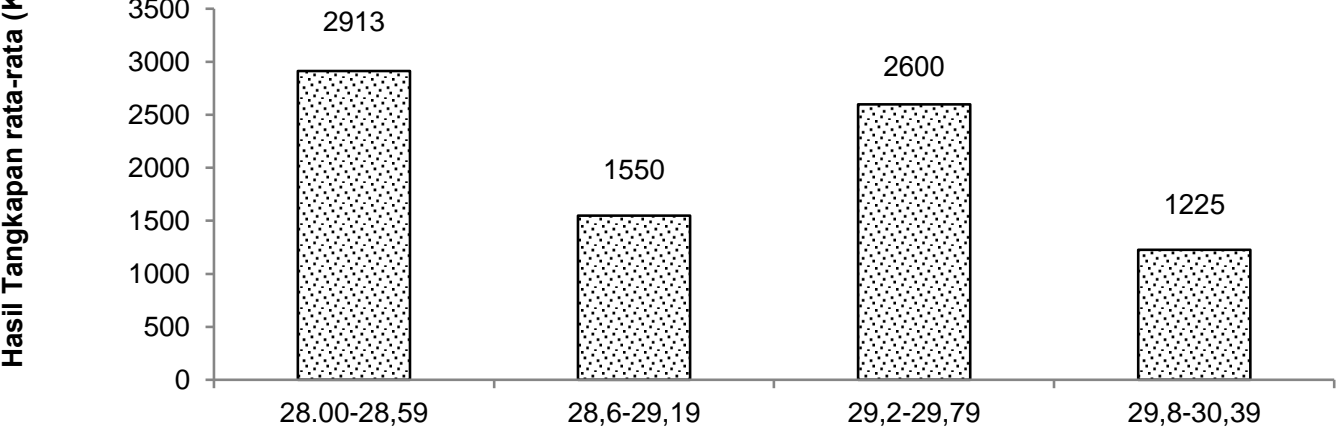

SPL $\left({ }^{\circ} \mathrm{C}\right)$

Gambar 6. Hubungan SPL terhadap jumlah hasil tangkapan ikan Cakalang

$x 2=$ salinitas $(\%)$

r2 = koefisien berganda

$$
r=\frac{\left(n \sum X Y\right)-\left(\sum X\right)\left(\sum Y\right)}{\sqrt{n \sum X^{2}-\left(\sum X\right)^{2} \cdot\left(n \sum Y^{2}\right)-\left(\sum Y\right)^{2}-\left(\sum Y\right)^{2}}}
$$

\section{Catatan:}

1. Bila $r=0$ artinya semakin mendekati titik nol, besarnya koefisien korelasi semakin lemah hubungan antara variable $\mathrm{x}$ dan $\mathrm{y}$ dimana kedua variabel tersebut benarbenar tidak mempunyai hubungan sama sekali;

2. Bila $r=+1$ berarti antara variable $x$ dan $y$ mempunyai hubungan yang bersifat positif dan sempurna. Artinya semakin besar nilai $x$ akan semakin besar nilai $y$ dan sebaliknya; 
3. Bila $r=-1$ berarti antara variable $x$ dan $y$ mempunyai hubungan yang bersifat negatif (korelasi negatif) . Artinya semakin besar nilai $x$ akan semakin kecil nilai y dan sebaliknya.

\section{HASIL DAN PEMBAHASAN}

Hasil

Komposisi hasil tangkapan ikan cakalang pada bulan Desember 2018-
Maret 2019 cenderung mengalami fluktuasi. Data hasil tangkapan yang dikumpulkan dari kapal pukat cincin dengan jumlah setting secara keseluruhan sebanyak 25 kali setting. hasil tangkapan terbanyak pada bulan Januari hasil tangkapan yang diperoleh sebanyak $28.970 \mathrm{~kg} /$ setting dengan CPUE sebesar $4.139 \mathrm{~kg} / \mathrm{unit}$. dan hasil

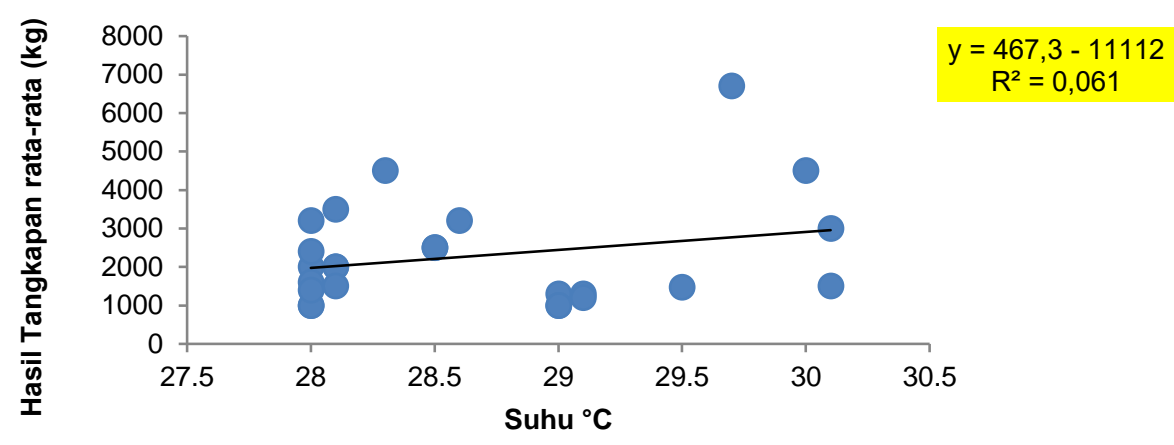

Gambar 7. Diagram pencar SPL dengan hasil tangkapan ikan cakalang Tabel 3. Frekuensi kelas penyebaran panjang ikan Cakalang

\begin{tabular}{ccccc}
\hline $\begin{array}{c}\text { Interval Kelas } \\
(\mathbf{c m})\end{array}$ & $\begin{array}{c}\text { Frekuensi } \\
\text { Total }\end{array}$ & $\mathbf{2 8}^{\circ} \mathbf{C}$ & $\mathbf{2 9}^{\circ} \mathbf{C}$ & $\mathbf{3 0}^{\circ} \mathbf{C}$ \\
\hline $21-25$ & 29 & 11 & 10 & 8 \\
$26-30$ & 139 & 55 & 43 & 41 \\
$31-35$ & 289 & 108 & 107 & 74 \\
$36-40$ & 161 & 87 & 51 & 23 \\
$41-45$ & 87 & 80 & 7 & 0 \\
$46-50$ & 36 & 20 & 16 & 0 \\
$51-55$ & 3 & 1 & 2 & 0 \\
$56-60$ & 3 & 0 & 3 & 0 \\
$61-65$ & 0 & 0 & 0 & 0 \\
$66-70$ & 2 & 0 & 2 & 0 \\
$71-75$ & 1 & 1 & & 0 \\
\hline Jumlah & 750 & 363 & 241 & 146 \\
\hline
\end{tabular}




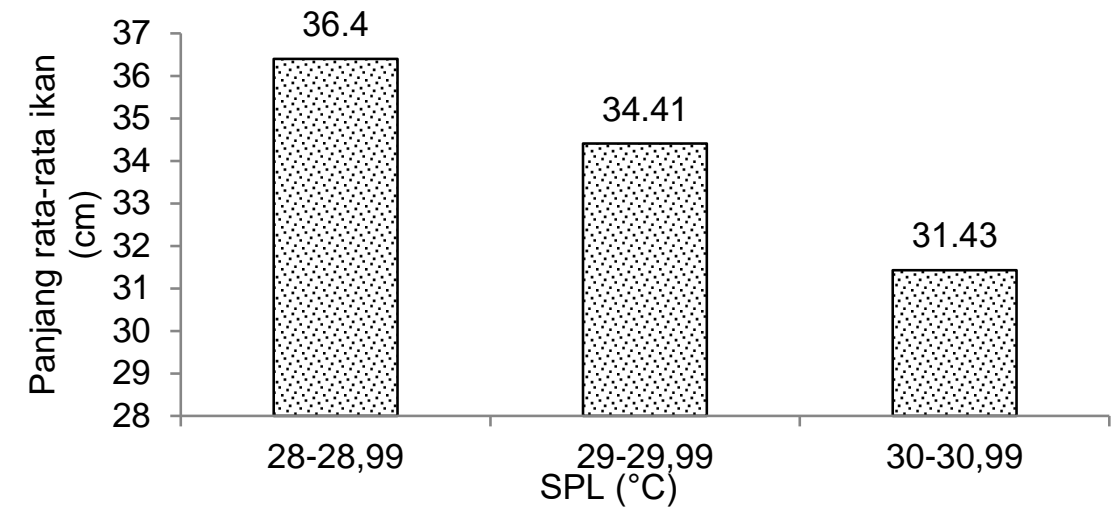

Gambar 8. Hubungan SPL terhadap ukuran panjang ikan Cakalang

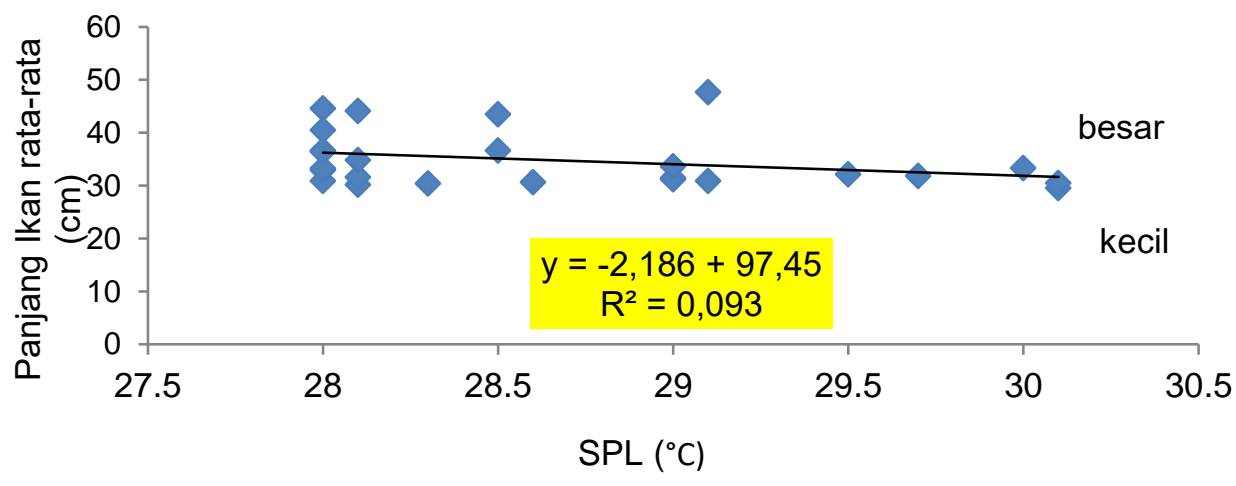

Gambar 9. Diagram pencar SPL terhadap ukuran panjang ikan Cakalang

tangkapan terendah pada bulan Maret hasil tangkapan yang diperoleh sebesar $2.400 \mathrm{~kg} /$ setting dengan CPUE sebesar $600 \mathrm{~kg} / \mathrm{unit}$.

\section{Ukuran Hasil Tangkapan}

Panjang ikan cakalang yang tertangkap selama bulan DesemberMaret berkisar antara 21-71 cm. Presentase ukuran ikan layak tangkap yang didapat pada trip penangkapan nelayan pukat cincin pada periode bulan Desember-Maret 2019 dapat dilihat pada Gambar 3 Kategori ukuran ikan layak tangkap sebesar 38\% (283 ekor) dan untuk ikan tidak layak tangkap sebesar $62 \% .(467$ ekor) dengan total jumlah sampel sebanyak 750 ekor.

Secara keseluruhan nilai kisaran ukuran panjang ikan cakalang yang tertangkap berada pada ukuran 30-44 $\mathrm{cm}$ dengan nilai rata-rata ikan sebesar 35 cm ukuran ikan cakalang yang ditangkap pada bulan Maret memiliki ukuran yang berbeda cukup singnifikan. Penangkapan ikan di atas ukuran pertama kali matang gonad dapat memberi peluang ikan target tangkapan untuk berproduksi dan memijah dahulu sebelum tertangkap. Sehingga proses 
Tabel 5. Pengelompokan frekuensi kelas menurut salinitas

\begin{tabular}{ccccccc}
\hline $\begin{array}{c}\text { Interval } \\
\text { Kelas (cm) }\end{array}$ & $\begin{array}{c}\text { Frekuensi } \\
\text { Total }\end{array}$ & $\mathbf{3 0} \mathbf{~ p p t}$ & $\mathbf{3 1} \mathbf{p p t}$ & $\mathbf{3 2} \mathbf{~ p p t}$ & $\mathbf{3 3} \mathbf{p p t}$ & $\mathbf{3 4} \mathbf{~ p t}$ \\
\hline $21-25$ & 29 & 3 & 5 & 3 & 8 & 10 \\
$26-30$ & 139 & 11 & 17 & 12 & 29 & 70 \\
$31-35$ & 289 & 32 & 49 & 35 & 70 & 103 \\
$36-40$ & 161 & 43 & 21 & 13 & 13 & 71 \\
$41-45$ & 87 & 24 & 26 & 6 & 0 & 31 \\
$46-50$ & 36 & 6 & 0 & 16 & 0 & 14 \\
$51-55$ & 3 & 1 & 0 & 2 & 0 & 0 \\
$56-60$ & 3 & 3 & 0 & 0 & 0 & 0 \\
$61-65$ & 0 & 0 & 0 & 0 & 0 & 0 \\
$66-70$ & 2 & 1 & & & & 2 \\
$71-75$ & 1 & & & & & 1 \\
\hline Jumlah & 750 & 124 & 118 & 87 & 120 & 301 \\
\hline
\end{tabular}

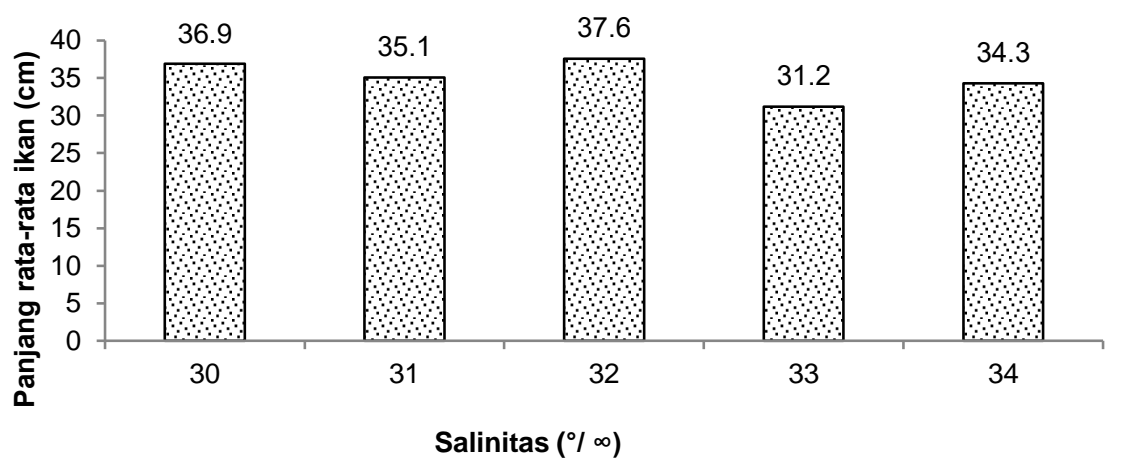

Gambar 12. Salinitas terhadap ukuran panjang ikan Cakalang

Salinitas $\%$

Gambar 11. Diagram pencar salinitas terhadap jumlah hasil tangkapan ikan Cakalang

perkembangbiakan fase kecil menjadi fase dewasa dapat berjalan Oleh karena itu penentuan layak tidaknya ikan tersebut ditangkap sangat berkaitan dengan penentuan selektivitas operasi penanagkapan ikan yaitu tidak membahayakan kelestarian sumber daya ikan target penangkapan. 


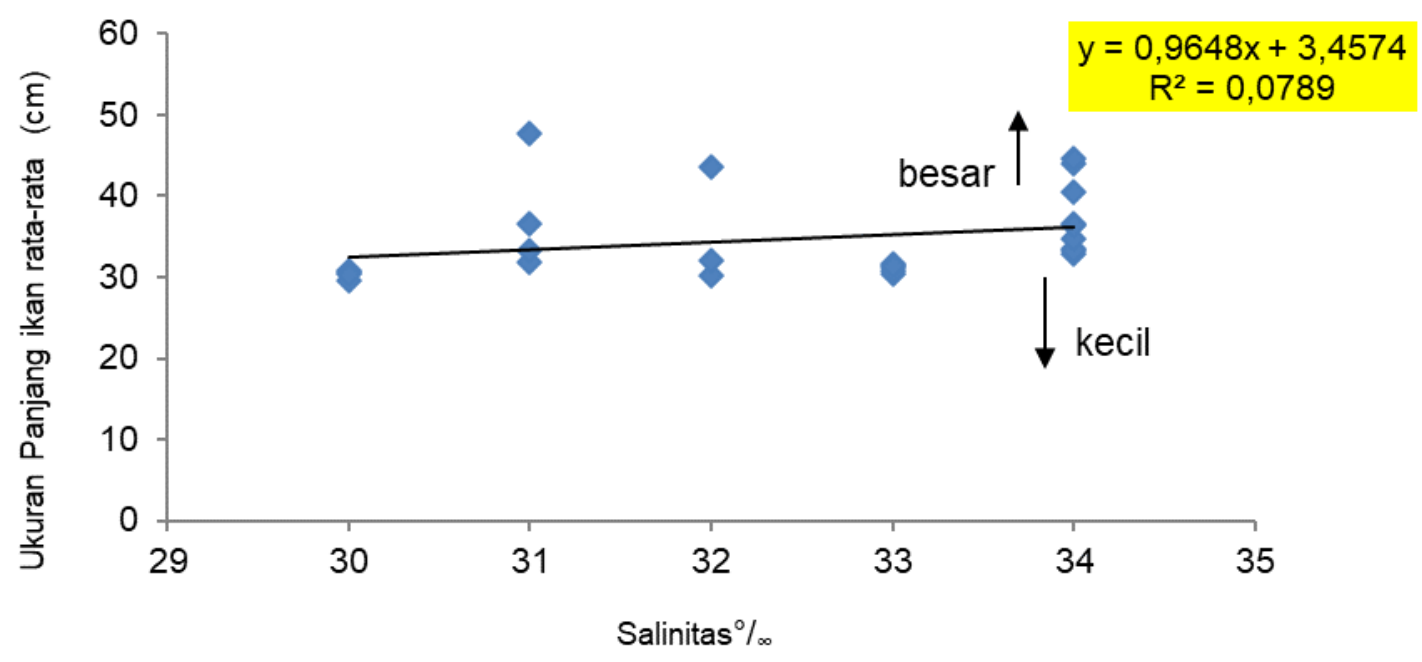

Gambar 13. Diagram sebaran Salinitas dengan ukuran panjang ikan Cakalang

\section{Pembahasan}

Hubungan Suhu Permukaan Laut Dengan Jumlah Hasil Tangkapan

Suhu permukaan laut dapat digunakan sebagai salah satu indikator keberadaan ikan pada suatu perairan. Setiap spesies ikan mempunyai toleransi nilai suhu tertentu yang disenangi untuk melangsungkan hidupnya sehingga mempengaruhi keberadaan dan penyebaran ikan di suatu perairan.

Penyebaran hasil tangkapan ikan cakalang dengan suhu permukaan laut terlihat bahwa hasil tangkapan ikan cakalang didapatkan pada suhu 28$29^{\circ} \mathrm{C}$, hal ini juga mengindikasikan bahwa suhu tersebut bisa dijadikan suhu optimum bagi penangkapan ikan cakalang.

Penyebaran hasil tangkapan ikan cakalang dengan suhu permukaan laut terlihat bahwa hasil tangkapan ikan cakalang yang tertangkap pada suhu $28^{\circ} \mathrm{C}$ sampai $30^{\circ} \mathrm{C}$ dengan persamaan regresi $Y=467.3-1111.2$ dengan nilai koefisien korelasi $(r=0.024)$ dan nilai determinasi $6.1 \%$ yang berarti hubungan suhu terhadap hasil tangkapan tidak erat atau terdapat faktor lain. Namun berdasarakan Gambar 7 terlihat suatu pola yang menunjukan bahwa ikan cakalang cederung tertangkap pada suhu $28^{\circ} \mathrm{C}$ dan $29^{\circ} \mathrm{C}$, hal ini selaras dengan pernyataan Gunarso (1998). Suhu optimum untuk penangkapan ikan cakalang di perairan Indonesia berkisar antara $28^{\circ} \mathrm{C}-29^{\circ} \mathrm{C}$ walapun suhu optimum tersebut terkadang bervariasi sesuai perubahan temporal dan spasial.

\section{Hubungan Suhu Permukaan Laut} dengan Ukuran Panjang Ikan Cakalang

Selama penulis melakukan penelitian diperoleh sampel ikan cakalang sebanyak 750 ekor dengan frekuensi panjang ikan berkisar antara 
21-71 cm dengan frekuensi tiap suhu 28$30^{\circ} \mathrm{C}$. Berikut frekuensi panjang ikan cakalang dapat dilihat pada Tabel 3.

Pada Gambar 8 ikan yang berukuran besar $(\geq 36.4 \mathrm{~cm})$ dominan tertangkap pada kisaran suhu 28.00$28.99^{\circ} \mathrm{C}$ dan ikan yang berukuran kecil ( $\leq$ $31.4 \mathrm{~cm}$ ) dominan tertangkap pada suhu $30-30.99^{\circ} \mathrm{C}$. Hal ini mengindikasikan ikan cakalang ukuran besar tersebar pada kisaran SPL yang lebih lebar 28.00$29.99^{\circ} \mathrm{C}$ sedangkan ikan cakalang ukuran kecil tersebar pada kisaran SPL yang lebih sempit $29-30^{\circ} \mathrm{C}$. Ikan cakalang berukuran besar tertangkap pada kisaran SPL yang bervariasi, sedangkan ikan kecil tertangkap pada kisaran suhu yang homogen.

Berdasarkan Gambar 9 uji statistik dengan ukuran panjang ikan cakalang dapat dihitung dengan menggunakan regresi linear sederhana yang diperoleh persamaan regresi $Y=-2.186+97.45$ nilai koefisien korelasi sebesar $(r=0.030)$ dan nilai determinasi $(9.3 \%)$ yang berarti hubungan suhu dengan ukuran panjang ikan tidak erat, namun berdasarkan Gambar 9 terlihat pola trend menunjukkan bahwa ikan ukuran kecil lebih dominan tertangkap pada suhu tinggi, sedangkan ikan ukuran besar lebih dominan pada suhu rendah maupun tinggi. Hal ini selaras dengan pendapat Simbolon Domu (2009) bahwa ikan cakalang kategori kecil cenderung tertangkap pada SPL yang memiliki suhu hangat, sedangkan ikan cakalang kategori besar tertangkap pada SPL yang lebih variatif hangat dan dingin.

\section{Hubungan Salinitas dengan Hasil Tangkapan Ikan Cakalang}

Salinitas perairan merupakan parameter oseanografi yang dapat digunakan untuk memperkirakan daerah penyebaran ikan disuatu perairan. Kisaran salinitas yang menjadikan daerah penyebaran ikan cakalang umumnya bersifat variasi menurut wilayah perairan. Salinitas daerah penelitiaan penulis berkisar antara 30$34 \%$ dengan rata-rata salinitas sebesar $32.14 \%$. Untuk lebih jelasnya perhatikan Tabel 4.

Hubungan hasil tangkapan ikan cakalang dengan salinitas dapat dilihat pada gambar 10 grafik rata-rata hasil tangkapan terbanyak terdapat pada kisaran salinitas $31-31.9 . \%_{\infty}^{\circ}$ Dengan total hasil tangkapan rata-rata 3.925 $\mathrm{kg} /$ setting. Kemudian hasil tangkapan terendah dengan salinitas $34-35 \%$ Ratarata hasil tangkapan sebesar 1.678 $\mathrm{kg} /$ setting.

Berdasarkan perhitungan salinitas terhadap hasil tangkapan ikan cakalang diperoleh persamaan regresi $Y=-$ $277.7+11301$ dengan nilai koefesien korelasi $(r=0.030)$ dan nilai determinasi $(9.3 \%)$ yang berarti hubungan salinitas 
terhadap hasil tangkapan sangat lemah. Namun terlihat bahwa hasil tangkapan ikan cakalang terdapat pada salinitas 30 dan $34 \%$. Hal ini juga dapat mengindikasikan bahwa salinitas tersebut bisa dijadikan salinitas yanag optimum bagi penangkapan ikan cakalang di Laut Maluku pada bulan Desember sampai Mei 2019. Hal ini selaras dengan pendapat Nontji (2007) faktor pembatas diri ikan cakalang yang penting ialah suhu dan salinitas dimana cakalang lebih banyak hidup pada perairan lapisan permukaan dengan suhu $16-30^{\circ} \mathrm{C}$ dan salinitas $32-36 \%$

\section{Hubungan Salinitas dengan Ukuran} Panjang Ikan Cakalang

Selama penulis melakukan penelitian diperoleh sampel ikan cakalang sebanyak 750 ekor dengan frekuensi panjang ikan berkisar antara 2$75 \mathrm{~cm}$ dengan frekuensi tiap salinitas 30$34 \%$. Berikut frekuensi panjang ikan cakalang dapat dilihat pada Tabel 5 .

Gambar 12 menyatakan bahwa pada kisaran salinitas $32 \%$ ukuran panjang ikan dengan ukuran rata-rata terbesar $37.6 \mathrm{~cm}$ dan untuk ukuran panjang terkecil didapat dengan kisaran salinitas $33 \%$ dengan ukuran $31.2 \mathrm{~cm}$.

Berdasarkan Gambar 13 menunjukan bahwa salinitas dengan ukuran panjang ikan cakalang dapat dihitung dengan menggunakan regresi linear sederhana $(Y=0.964+3.457$. nilai determinasi 7.9\%; nilai koofisien korelasi 0.028). Hubungan salinitas dengan ukuran panjang ikan cakalang adalah tidak erat, namun berdasarkan Gambar 13 terlihat pola bahwa ikan ukuran kecil lebih dominan tertangkap pada salinitas tinggi, sedangkan ikan ukuran besar tertangkap pada salinitas rendah maupun tinggi di Laut Maluku.

\section{SIMPULAN DAN SARAN}

Berdasarkan hasil penelitian maka ditarik kesimpulan sebagai berikut:

1. Berdasarkan perhitungan metode regresi dihasilkan $r=0.024$ untuk jumlah hasil tangkapan $r=0.030$ untuk panjang ikan cakalang, dan $r=0.030$ untuk salinitas terhadap jumlah hasil tangkapan dan $\mathrm{r}=0.028$ untuk salinitas terhadap ukuran panjang ikan cakalang hal ini menunjukan bahwa suhu dan salinitas terhadap jumlah dan ukuran panjang ikan cakalang tidak berpengaruh secara nyata.

2. Panjang ikan cakalang yang tertangkap selama bulan DesemberMaret berkisar antara 21-71 cm, ukuran ikan layak tangkap sebesar 38\% (283 ekor) dan untuk ikan tidak layak tangkap sebesar 62\%.(467 ekor) dengan total jumlah sampel sebanyak 750 ekor.

3. SPL di Laut Maluku pada bulan Desember 2018 berkisar $29-30^{\circ} \mathrm{C}$ 
dengan suhu dominan $30^{\circ} \mathrm{C}$, kisaran SPL Januari $201928-30^{\circ} \mathrm{C}$ dengan suhu dominan $29^{\circ} \mathrm{C}$, bulan Februari 2019 berkisar $29-30^{\circ} \mathrm{C}$ dengan suhu dominan $29^{\circ} \mathrm{C}$ dan untuk bulan Maret berkisar $28-31^{\circ} \mathrm{C}$ dengan suhu dominan $28^{\circ} \mathrm{C}$. Kemudian, salinitas bulan Desember 2018Januari 2019 berkisar 33.5-34\% bulan Februari-Maret berkisar 33.5$35 \%$ cakalang sering tertangkap pada kisaran suhu 28$30^{\circ} \mathrm{C}$ dan salinitas $30-33 \%$.

Upaya yang dapat dilakukan untuk mendapatkan hasil tangkapan ikan cakalang dengan ukuran panjang ikan $(\geq$ $36.4 \mathrm{~cm}$ ), dilihat dari parameter oseanografi suhu dan saliitas terdapat suatu pola yang menunjukan ikan cakalang berukuran besar cenderung menyukai suhu di bawah $28^{\circ} \mathrm{C}$ dan salinitas di bawah $32 \%$. Sehingga perlu dilakukan penambahan kedalaman jaring $(\geq 60$ ) meter serta merubah ukuran mata jaring menjadi 5 inchi untuk sayap dan 3 inchi untuk kantong. Diharapkan ikan yang belum layak tangkap terhindar dari upaya penangkapan yang dilakukan.

\section{DAFTAR PUSTAKA}

Firdaus, Maulana. 2018. "Profil Perikanan Tuna dan Cakalang di Indonesia." (021):23-32.
Gunarso, W. 1998. Tingkah laku ikan dan perikanan pancing.

Matsumoto, Walter M., Robert A. Skillman, dan Andrew E. Dizon. 1984. Synopsis of biological data on skipjack tuna, Katsuwonus pelamis.

Nontji, Anugerah. 2007. Laut Nusantara. Djambatan.

Sibagariang, Onolawe Prima, Fauziyah Fauziyah, dan Fitri Agustriani. 2011. "Analisis potensi lestari sumberdaya perikanan tuna longline di Kabupaten Cilacap, Jawa Tengah." Maspari Journal 3(2):24-29.

Simanjuntak, Donald H., Lawrence J. L. Lumingas, dan Joudy R. R. Sangari. 2019. "Sustainable Potential of Tuna Fishery Around the Waters of North Sulawesi Province Based on Data from the Bitung Ocean Fisheries Port (PPS)." Jurnal Perikanan Dan Kelautan Tropis 10(1):18.

Simbolon Domu. 2009. "Eksplorasi

Daerah Penangkapan Ikan

Cakalang Melalui Analisis Suhu Permukaan Laut dan Hasil Tangkapan di Perairan Teluk Palabuharatu." Jurnal Mangrove dan Pesisir 10(1):42-49. 
Tangke, Umar, John W. Ch. Karuwal, Achmar Mallawa, dan Mukti Zainuddin. 2016. "Analisis Hubungan Suhu Permukaan Laut, Salinitas dan Arus dengan Hasil Tangkapan Ikan Tuna di Perairan Bagian Barat Pulau Halmahera." Jurnal IPTEKS PSP 3(5):368-82.
Walpole, Ronald E. 1995. Pengantar IImu Statistik Edisi 3. PT. gramedia Pustaka Utama. 